\title{
Immunohistochemical analysis of HLA (A, B, C) antigens in liver disease using a monoclonal antibody
}

\author{
C BARBATIS, J WOODS, J A MORTON, K A FLEMING, A McMICHAEL, AND J O'D McGEE* \\ From the University of Oxford, Nuffield Departments of Pathology and Medicine, John Radcliffe Hospital, \\ Oxford
}

SUMMARY The distribution of HLA class I antigens was studied in 42 liver biopsies and eight necropsies by an immunoperoxidase technique employing a monoclonal antibody which reacts with the heavy chains of class I (A, B, C) HLA antigens. In normal liver HLA class I antigens could not be detected on hepatocyte cell membranes or cytoplasm; these antigens were present on the cell membrane of bile duct epithelium, on sinusoidal lining cells, fibroblasts, and blood vessel endothelium. However, in all patients with actue alcoholic hepatitis, most cases of primary biliary cirrhosis and some cases of chronic active hepatitis HLA class I antigens were detectable focally or diffusely on the cell membrane of hepatocytes; in two cases of acute viral hepatitis (non-A, non-B) HLA class I antigens were present in granular form in the cytoplasm of all hepatocytes. These findings may be relevant to the prolonged survival of liver allografts in man and other species and in the pathogenesis of some liver diseases.

The major histocompatibility complex (MHC) comprises class I (A, B, C) antigens, class II (DR or Ia), which modulate immune responsiveness, ${ }^{123}$ and class III antigens, which control $\mathrm{C}^{4}, \mathrm{C}^{5}$, and $\mathrm{B}_{\mathrm{f}}{ }^{6}$ complement components.

Class I antigens function mainly as major transplantation antigens and as binding sites for cytotoxic $T$ cells. $^{37}$ The latter appear to exert their cytolytic action against virus infected, ${ }^{8-13}$ hapten or chemically sensitised ${ }^{1415}$ target cells only when $T$ cells and target cells share the same class I antigens. Cell lines infected with virus but lacking class I antigens resist cytolysis by appropriately sensitised $T$ cells. ${ }^{16}$

Previous data have suggested that class I antigens are present in almost all nucleated cells except red cells and trophoblast. ${ }^{17}$ This was based on absorption studies ${ }^{18}$ using polyclonal antibodies and on microcytotoxicity assays. ${ }^{1920}$ More recent studies, however, on intact tissues using polyclonal antibodies, ${ }^{21} 22$ and monoclonal antibodies to HLA class I antigens ${ }^{23} 2425$ have shown that in addition to quantitative differences among tissues, certain cells in many tissues do not show detectable HLA class I antigens.

\footnotetext{
*Address for correspondence: as above
}

Received for publication 17 August 1981.
In this paper the distribution of HLA class I antigens in human adult liver in normality and liver diseases is reported.

\section{Methods}

Forty-two percutaneous needle liver biopsies were collected at the time of biopsy, immediately frozen and stored in liquid nitrogen. Liver tissue from eight necropsies of patients with alcoholic liver disease (up to 48 hours post mortem) were similarly handled. All cases were $\mathrm{Hb}_{\mathrm{s}} \mathrm{Ag}$ seronegative by radio-immunoassay.

Chang liver cells from a human liver cell line (Gibco-Biocult, Paisley, Scotland), and Alexander liver cells, which produce $\mathrm{Hb}_{\mathrm{s}} \mathrm{Ag}$ but apparently not $\mathrm{Hb} \mathrm{Ag}$, were cultured on glâss slides for 48 hours and studied for the distribution of HLA class I antigens. All cell lines were cultured in RPM1 1640 medium (Gibco Laboratories) containing glutamine, $10 \%$ fetal calf serum, and $10000 \mathrm{IU} / \mathrm{ml}$ penicillin, 10 $\mu \mathrm{g} / \mathrm{ml}$ streptomycin, $25 \mu \mathrm{g} / \mathrm{ml}$ fungizone, in $95 \%$ air and $5 \% \mathrm{CO}_{2}$.

The mouse monoclonal antibody to HLA class I antigens (PA 2.6) has been previously described ${ }^{26}$; it is secreted by a hybrid myeloma cell line generated by Parham and Brodsky and cloned by McMichael. ${ }^{26}$ This antibody binds to the heavy 
chains of A, B, C HLA antigens and precipitates a molecule from lymphocyte membranes which is composed of two subunits of approximate molecular weight 43000 and 12000 daltons. Mouse (Balb-C) ascitic fluid from the hybridoma line producing this antibody was diluted $1 / 1000$ in $0.01 \mathrm{M}$ phosphate buffer (pH 7.4) containing $0.15 \mathrm{M} \mathrm{NaCl}$ (PBS) and used for detection of the HLA class I antigens in the immunohistochemical procedure described below.

Cryostat sections (4-6 $\mu$ thick) and cell monolayers were air dried for one hour at $37^{\circ} \mathrm{C}$, fixed in cold acetone, $-20^{\circ} \mathrm{C}$, for 15 minutes, and air dried at $22^{\circ} \mathrm{C}$. After washing in PBS for 10 minutes they were incubated with the monoclonal antibody for one hour at $22^{\circ} \mathrm{C}$, washed in PBS and treated with peroxidase conjugated anti-mouse IgG (Dakopatts, Copenhagen) diluted $1 / 60$ in PBS containing $1 \%$ (vol/vol) normal human serum. Negative controls included replacement of the anti-HLA antibody with ascitic fluid from a mouse inoculated with a hybridoma line which produced anti-Mallory body antibody in vitro but stopped producing anti-MB antibodies in vivo ${ }^{27}$; this ascitic fluid contained mouse
Ig; replacement of the anti-HLA antibody with antiplatelet $^{28}$ and anti-MB antibodies, ${ }^{27}$ and the peroxidase conjugated reagent alone. Positive controls consisted of staining smears of peripheral blood mononuclear cells isolated in lymphoprep gradient with the monoclonal antibody to HLA described above. ${ }^{29}$

\section{Results}

In normal liver, hepatocytes do not exhibit detectable HLA class I antigens as defined by PA 2.6 either on the cell membrane or in the cytoplasm. Bile duct epithelium, sinusoidal lining cells, all blood vessel endothelium, and fibroblasts showed strongly positive membrane staining (Figs. 1 and 2). HLA A, B, C antigens were also demonstrable in the cytoplasm of sinusoidal lining cells (Fig. 2).

In all cases of acute alcoholic hepatitis (with or without chronic alcoholic liver disease), most cases of primary biliary cirrhosis, and some cases of acute or chronic hepatitis HLA class I antigens were detected on the cell membrane of hepatocytes (Table 1). HLA distribution was mainly focal: only small groups of

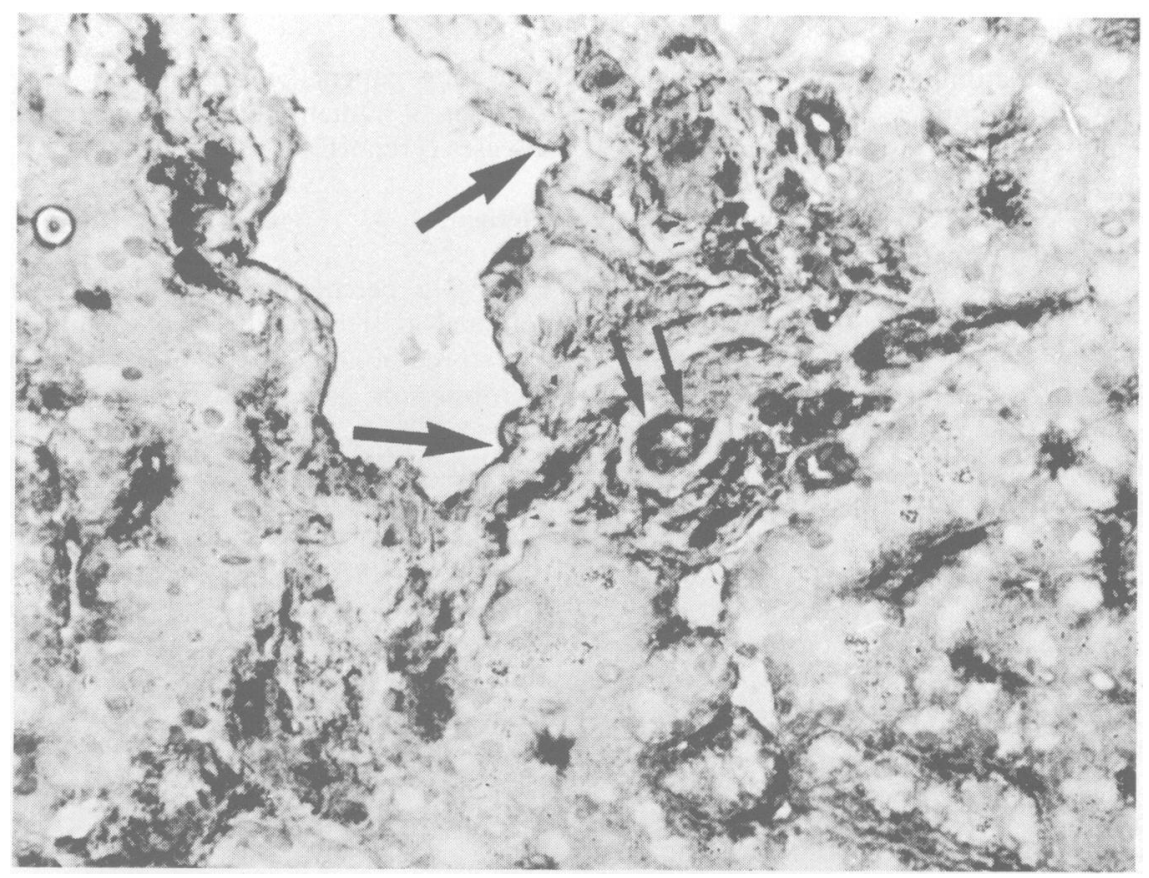

Fig. 1 HLA class I detection in normal liver. Sinusoidal lining cells, endothelial cells (large arrows), bile duct epithelium (small arrows), and fibroblasts in portal tracts contain these antigens. Hepatocytes are entirely negative in this immunoperoxidase preparation with monoclonal antibody to HLA A,B,C antigens. All preparations illustrated in Fig. 1-6 were lightly counterstained with haematoxylin, $\times \mathbf{4 0 0}$ (original magnification in this and following figures). 


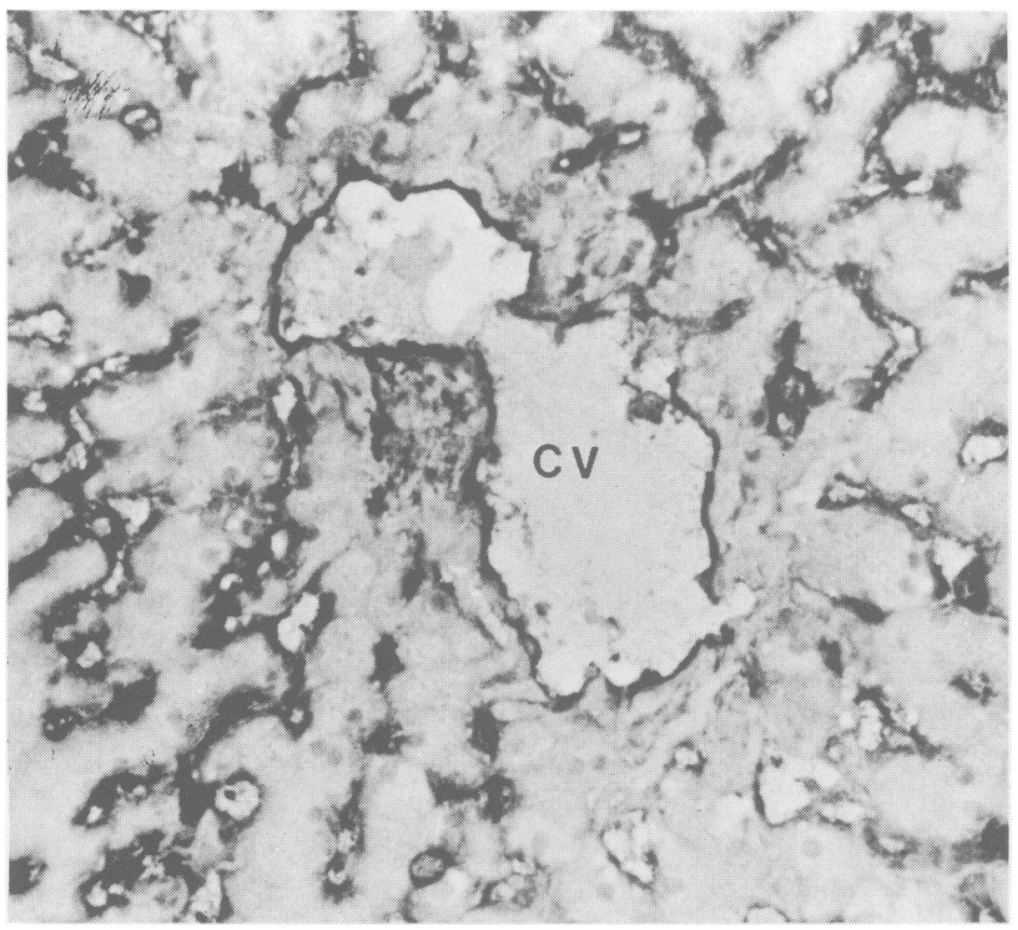

Fig. 2 HLA class I antigen detection in normal liver determined by the immunoperoxidase procedure. Endothelium of the central vein $(C V)$ and sinusiodal lining cells contain HLA antigens. The latter cannot be detected in any hepatocyte, $\times 500$.

Table 1 Detection of HLA class I antigens in hepatocytes in normality and liver disease

\begin{tabular}{llll}
\hline Condition & $\begin{array}{l}\text { No. of } \\
\text { cases }\end{array}$ & \multicolumn{2}{l}{ No.of cases showing hepatocyte HLA } \\
\cline { 3 - 4 } & & Membrane & Cytoplasm \\
\hline Normality & 8 & 0 & 0 \\
$\begin{array}{l}\text { Acute alcoholic } \\
\text { hepatitis without } \\
\text { cirrhosis }\end{array}$ & 3 & $3(\mathrm{~F})^{*}$ & 0 \\
$\begin{array}{l}\text { Alcoholic hepatitis } \\
\text { and cirrhosis }\end{array}$ & 10 & $8(\mathrm{~F})$ & 0 \\
Alcoholic fibrosis & 6 & $2(\mathrm{D})$ & 0 \\
Alcoholic cirrhosis & 3 & $3(\mathrm{~F})$ & 0 \\
PBC & 5 & 0 & 0 \\
CAH & 3 & $4(\mathrm{~F})$ & 0 \\
Acute hepatitis & 3 & $2(\mathrm{~F})$ & 0 \\
Miscellaneous & 9 & 0 & 2 \\
\hline
\end{tabular}

*F : focal positivity of hepatocytes for HLA class I (see Figs 3 and 4). D : diffuse membrane staining of hepatocytes throughout the biopsy (see Fig. 5).

hepatocytes showed cell membrane staining and were predominantly located in the periportal zone (Fig. 3). All cases of alcoholic liver disease examined (Table
1) showed variable degrees of fatty change; however, in this series there were no cases of simple fatty change only.

In two cases of acute alcoholic hepatitis superimposed on alcoholic cirrhosis, almost every hepatocyte exhibited cell membrane staining (Fig. 4). Two cases of non-A, non-B hepatitis did not show membrane HLA but, instead, there was a diffuse cytoplasmic granular staining with stimultaneous reduction in the intensity of staining of sinusoidal lining cells. Of nine cases of miscellaneous aetiology only one (due to large duct obstruction) showed HLA class I positivity on hepatocyte cell membranes (Table 2).

HLA class I antigens were readily detected on the cell membrane only of the Alexander cells (Fig. 5), while they could not be detected on Chang cell membranes.

The anti-Mallory body and anti-platelet monoclonal antibodies produced a different distribution of staining patterns from that recorded above. The cell structures which react with these monoclonal antibodies immunohistochemically have been published elsewhere. ${ }^{27} 28$ The ascitic fluid from a clone which had stopped producing anti-MB antibody but contained mouse Ig gave entirely negative results. In all experiments the HLA class I monoclonal antibody was shown to react with the membrane of platelets and leucocytes as previously reported. ${ }^{23}$ 


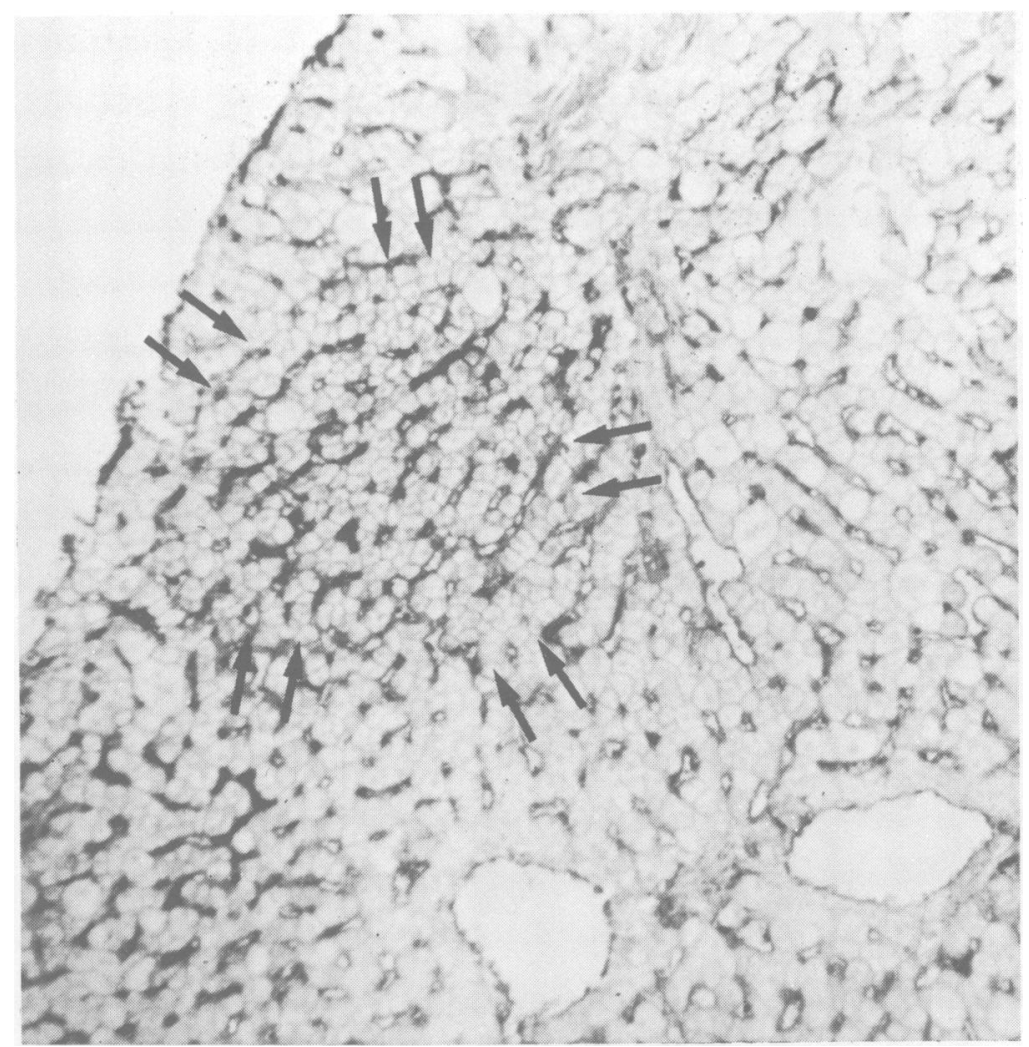

Fig. 3 HLA distribution in liver in acute alcoholic hepatitis. In addition to the presence of HLA class I antigens on endothelial and sinusoidal lining cells the same antigens are also present on the cell membranes of many hepatocytes particularly in the focus outlined by arrows. Immunoperoxidase, $\times 200$.

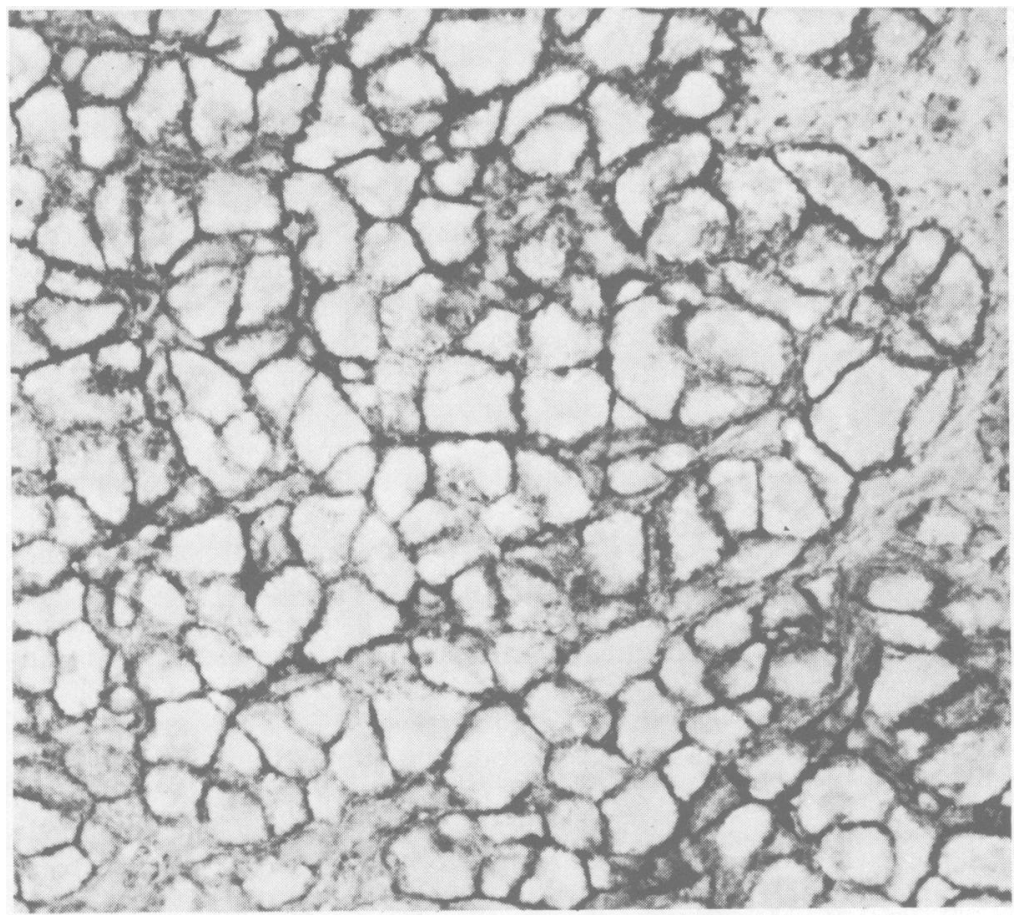

Fig. 4 HLA detection in alcoholic cirrhosis. The cell membrane of every hepatocyte stains strongly for class I antigens. Immunoperoxidase preparation, $\times 500$. 
Table 2 Distribution of HLA class $I$ antigens on hepatocytes in miscellaneous liver diseases

\begin{tabular}{|c|c|c|c|}
\hline \multirow[t]{2}{*}{ Condition } & \multirow{2}{*}{$\begin{array}{l}\text { No. of } \\
\text { cases }\end{array}$} & \multicolumn{2}{|c|}{ No. of cases showing hepatocyte $H L A$} \\
\hline & & Membrane & Cytoplasm \\
\hline Drug* cholestasis & 1 & 0 & 0 \\
\hline Sclerosing cholangitis & 1 & 0 & 0 \\
\hline Metastatic carcinoma & 1 & 0 & 0 \\
\hline Bile duct obstruction & 1 & $+(\mathrm{F})$ & 0 \\
\hline $\begin{array}{l}\text { Portal triaditis } \\
\text { (drug addict) }\end{array}$ & 1 & 0 & 0 \\
\hline Hairy cell leukaemia & 1 & 0 & 0 \\
\hline $\begin{array}{l}\alpha_{1} \text {-antitrypsin } \\
\text { deficiency }\end{array}$ & 1 & 0 & 0 \\
\hline Haemochromatosis & 1 & 0 & 0 \\
\hline Hepatoma & 1 & 0 & 0 \\
\hline
\end{tabular}

F : focal positivity of hepatocytes for HLA class I. * : chlorpromazine.

\section{Discussion}

Studies based on absorption of anti-HLA antibodies with human whole liver homogenates ${ }^{1824}$ have demonstrated that liver contains HLA class I antigens. It is shown here, however, that HLA class I antigens are not uniformly distributed on all cell populations in normal liver. They are detectable by immunoperoxidase techniques only on the cell surface of bile duct epithelium, endothelium of all blood vessels and fibroblasts but are not detectable on normal hepatocytes. In a recent survey of HLA $(A, B, C)$ antigens in various normal tissues and mammary cancers (using indirect immunofluorescence) Fleming et al. ${ }^{25}$ reported the same distribution of these antigens in normal liver as recorded here. The inability of monoclonal antibody PA 2.6 to detect class I antigens in normal hepatocytes could be due to the fact that these molecules assume a different conformation on hepatocyte plasma membranes, or that these membranes are inaccessible to monoclonal antibodies. The first of

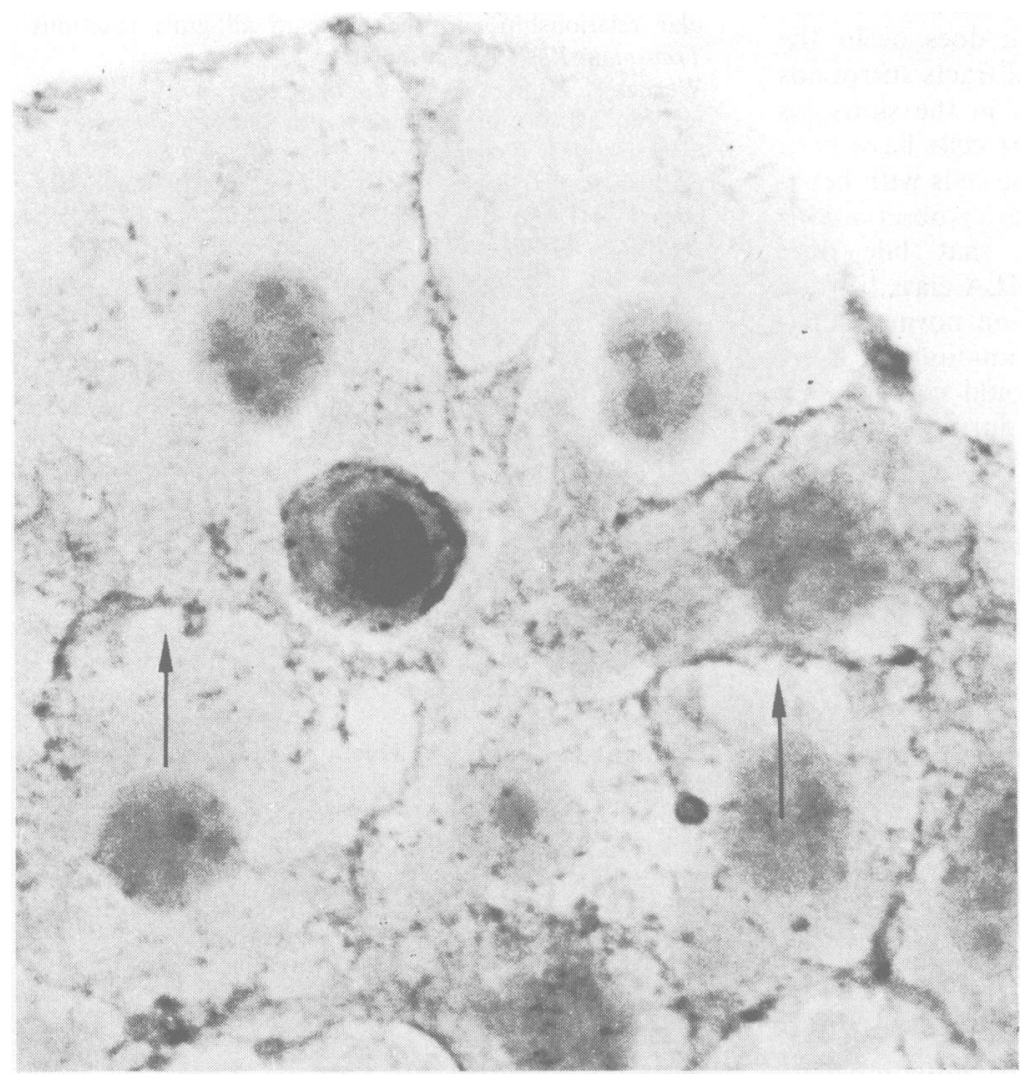

Fig. $5 H L A(A, B, C)$ is present on the cell membranes (arrows) of Alexander cells maintained in vitro. Immunoperoxidase, $\times 800$. 
these possibilities cannot be excluded in this investigation; the second possibility seems unlikely, as monoclonal antibodies to antigens unrelated to HLA react with hepatocyte membranes in frozen sections (unpublished observations). It is also possible that the procedures used here are not sensitive enough to detect small amounts of class I antigens. It should be noted, however, that the monoclonal antibody to class I antigens used here detects about 5000 molecules of these antigens on cell surfaces. ${ }^{25}$ Direct comparison of immunofluorescence and immunoperoxidase staining with the same antibody has shown that the latter method is more sensitive (unpublished observations). The sensitivity of the immunoperoxidase procedure, however, does not exclude the presence of small amounts of HLA (A, B, C) on hepatocyte cell membranes.

Allogeneic human liver grafts show a low incidence of rejection compared with renal and heart transplants. Several investigations have shown that HLA compatibility is not of paramount importance in liver transplantation; that hyperacute rejection never occurs in liver; that acute rejection is easily controlled, and chronic rejection is rare. ${ }^{3031}$ Morphological observations on rejected liver allografts indicate that when rejection does occur the mononuclear infiltrate in the portal tracts surrounds and involves bile duct epithelium; in the sinusoids foamy histiocytes and mononuclear cells have been described but direct contact of these cells with hepatocytes is not common. ${ }^{30}{ }^{31}$ The latter observations may be explained by the fact that bile duct epithelium and sinusoids contain HLA class I, while these antigens cannot be detected on normal hepatocytes. The absence of detectable amounts of HLA class I antigens on hepatocytes could confer resistance to T-cell mediated rejection during transplantation, assuming that hepatocyte rejection is HLA class I dependent.

HLA class I antigens were detected either focally or diffusely on hepatocyte cell membranes in acute and chronic alcoholic liver disease and other chronic diseases of inflammatory type. One explanation of these findings is that certain clones of hepatocytes can express HLA (A, B, C) on the cell surface after exposure to alcohol or other agents. It is conceivable that the detection of HLA (A, B, C) on hepatocyte cell membranes may not necessarily indicate induction of expression of HLA but absorption from plasma; however, the focal distribution of HLA in most cases makes the latter mechanism less probable. In two cases of non-A, non-B hepatitis diffuse granular cytoplasmic HLA was observed. This also may be due either to induction of HLA expression or diffusion of HLA (A, B, C) antigens into damaged hepatocytes. The presence of HLA (A, B, C) antigens on the cell membrane or in the cytoplasm of hepatocytes in all of these diseases may render them susceptible to sensitised cytotoxic $T$ cells and hence to perpetuation of liver cell damage.

The detection of HLA class I antigens on Alexander cells, but the apparent lack of these antigens on Chang liver cells raises the possibility that these cell lines could be used for in vitro analysis of the mechanisms regulating HLA expression in hepatocytes.

The absence of HLA (A, B, C) in sinusoidal lining cells in two cases of non-A, non-B acute viral hepatitis could be due to cell damage or circulating blocking antibody to HLA class I.

Alexander cells were obtained from Dr H Thomas's laboratory, Royal Free Hospital, London. Dr K A Fleming was supported by the Wellcome Trust and Jansen Pharmaceuticals. Miss T Chisnall typed the manuscript.

\section{References}

${ }^{1}$ Klein J, Hauptfeld, V. Ia antigens: their serology, molecular relationship and their role in allograft reactions. Transplant Rev 1976; 30:83-99.

2 Wernet P. Human Ia-type alloantigens: methods of detection, aspects of chemistry and biology, markers of disease states. Transplant Rev 1976; 30:271-98.

${ }^{3}$ Barnstable CJ, Jones EA. Isolation, structure and genetics of HLA-A-B-C and DRW (1a) antigens. $\mathrm{Br} \mathrm{Med}$ Bull 1978; 34:241-6.

${ }^{4}$ Alper CA. Inherited structural polymorphism in human $C_{2}$. Evidence for genetic linkage between $C_{2}$ and $B_{f} J$ Exp Med 1976; 144:1111-5.

${ }^{5}$ Shreffler DC. The $\mathrm{S}$ region of the mouse major histocompatability complex (H-2); genetic variation and functional role in complement system. Transplant Rev 1976; 32:140-67.

${ }^{6}$ Allen FH. Linkage of HL-A and GBG. Vox Sang 1974; 27:382-4.

${ }^{7}$ Klein J. The major histocompatability complex of the mouse. Science 1979; 203:516-21.

${ }^{8}$ Zinkernagel MR, Doherty PC. Immunological surveillance against altered self components by sensitised $T$ lymphocytes in lymphocytic choriomeningitis. Nature 1974; 251 :547-8.

${ }^{9}$ Gomard, E., Duprez V, Henin Y, Levy JP. H-2 region product as determinant in immune cytolysis of syngeneic tumour cells by anti-MSV T lymphocytes. Nature 1976; 260: 707-9.

${ }^{10}$ McMichael AJ, Ting A, Zweerink HS, Asconas BA. HLA restriction of cell mediated lysis of influenza virus infected human cells. Nature 1977; 270:524-6.

${ }^{11}$ Kreth HW, V ter Meulen, Eckert G. Demonstration of HLA restricted killer cells in patients with acute measles. Med Microbiol Immunol 1979; 165:203-14.

12 Moss DJ, Rickinson AB; Pope JH. Long term T-cell 
mediated immunity to Epstein-Barr virus in Man. III. Activation of cytotoxic $T$ cells in virus infected leucocyte culture. Int J Cancer 1979; 23:618-25.

${ }^{13}$ McMichael, AJ. HLA restriction of human cytotoxic T cells. Springer Seminar on Immunopathology 1980; 3:3-22.

${ }^{14}$ Shearer GM, Schmitt-Verhulst AM. Major histocompatability complex restricted cell-mediated immunity. $A d v$ Immunol 1977; 55-91.

${ }^{15}$ Dickmeiss E, Soeberg B, Svejgaard A. Human cellmediated cytotoxicity against modified target cells is restricted by HLA. Nature 1977 ; 270:526-8.

${ }^{16}$ Tursz T, Fridman WH, Senik A, Tsapis A, Fellons M. Human virus-infected target cells lacking HLA antigens resist specific T-lymphocyte cytolysis. Nature 1977; 269:806-8.

${ }^{17}$ Amos DB, Kostyu DD. HLA-A central immunological agency in man. Adv Hum Genet, 1980; 10:137-208.

${ }^{18}$ Berah, M., Hors J, Dausset J. A study of HLA-A antigens in human organs. Transplantation 1970; 9:185-93.

19 Mattiuz PL, Massobrio M, Richiardi P. Espressione degli antigens del sistema HL-A sulle cellule fetali. Minerva Ginecol, 1973; 25:8-13.

${ }^{20}$ Seigler HF, Metzgar RS. Embryonic development of human transplantation antigens. Transplantation 1970; 9:478-86.

21 Jones JV, Cowan JD, Cumming J. HLA antigens on glomeruli. Transplantation 1972; 14:798-802.

${ }_{22}$ Sybesma JPh, Kater L, Borst-Eilers E, De Planque BA, Van Soelen T, Tuit G. HLA antigens in kidney tissue. Transplantation 1974; 17:576-9.

${ }^{23}$ Brown G, Biberfeld P, Christensson B, Mason DY. The distribution of HLA on human lymphoid, bone marrow and peripheral blood cells. Eur J Immunol 1979; 9:272-5.

${ }^{24}$ Williams KA, Hart DNJ, Fabre JW, Morris PJ. Distribution and quantitation of HLA-ABC and DR(Ia) antigens on human kidney and other tissues. Transplantation 1980; 29:274-9.

${ }^{25}$ Fleming KA McMichael A, Morton JA, Woods J, McGee JO'D. Distribution of HLA Class I antigens in normal human tissue and in mammary cancer. $J$ Clin Pathol 1981; 34:779-84.

${ }^{26}$ Brodsky FM, Parham P, Barnstable CJ, Crumpton MJ, Bodmer WF. Monoclonal antibodies for analysis of the HLA system. Immunology Rev 1979; 47:3-61.

${ }^{27}$ Morton JA, Bastin J, Fleming KA, McMichael A, Burns J, McGee JO'D. Mallory bodies in alcoholic liver disease: identification of cytoplasmic filament/cell membrane and unique antigenic determinants by monoclonal antibodies. Gut 1981; 22:1-7.

${ }^{28}$ McMichael A, Rust NA, Pilsh JR, Sochynsky RA, Morton JA, Mason DY, Ruan C, Tobelem G, Caen J. Monoclonal antibody to human platelet glycoprotein I. Immunological studies: Br J Haematol 1981; (in press).

${ }^{29}$ Böyum A. Isolation of mononuclear cells and granulocytes from human blood. Scand J Clin Lab Invest 1968; Suppl 97; 29:77-89.

${ }^{30}$ Starzl TE, Porter KA, Putnam CN, Schroter GPJ, Halgrimson CG, Weil 111 R, Hoelscher M, Reid HAS. Orthotopic liver transplantation in ninety three patients. Surg Gynec Obstet 1976; 142:487-505.

${ }^{31}$ Calne RY, McMaster P, Portmann B, Wall WJ, Williams $\mathbf{R}$. Observations on preservation, bile drainage and rejection in 64 orthotophic liver allografts. Ann Surg 1977; 186: $282-90$. 